\title{
Magnifying Employee Performance During The Covid-19 Pandemic: The Role Of Employee Empowerment In MSME Food Manufacturing Industries In Kerala.
}

\author{
Prasob K ${ }^{1}$, Dr. Amudha $\mathbf{R}^{2}$ \\ ${ }^{1}$ Research Scholar, Dept. of Management Studies, Karunya Institute of Technology \&Sciences, Coimbatore, Tamilnadu \\ ${ }^{2}$ Associate Professor, Dept. of Management Studies, Karunya Institute of Technology \&Sciences, \\ Coimbatore, Tamilnadu
}

\begin{abstract}
This study is a part of more in-depth research investigating the employee performance-enhancing factors and the role of empowerment during the Covid-19 pandemic in selected MSME food manufacturing industries in Kerala. This research focuses on introducing and testing a model to show the relationship between employee empowerment and employee performance. A conceptual framework was developed to identify the areas in which a literature review was performed. The conceptual framework is on employee empowerment, employee satisfaction, and employee commitment deciding the effectiveness and impact on employee performance. In the present research, employee performance is the key dependent variable. From 110 employees, the response ollected via a survey-based structured questionnaire. Collected responseswere analyzed, and formulated hypotheses were tested using standard statistical tools such as mean, standard deviation, one-sample t-test, correlation coefficient. The responsesanalyzed and hypotheses testing have resulted in a particular phenomenon.
\end{abstract}

Keywords: employee empowerment, employee commitment, employee performance.

\section{INTRODUCTION}

Employee performance is a crucial factor that contributes directly to the overall effective performanceof the company. With increased competition in the business arena, companies today are keen to boost employee performance, profitability, market reach, and brand recognition. Employee performancemeasurement is not an easy task, and companies need to plan it well to execute itfor desired results. If a company wants to assess all employees' performance levels, the owner requires proper planning with the performance administrator. Based on that discussion, specific standards must be established, and continuous employee evaluations must be done in various aspects. However, simple employee performance evaluation is not enough- and it requires mentoring and grooming sessions. Most organizations conduct training for their employees. Ridvan Arslan \& N. Tufan Uzaslan (2017) show that equipping overall performance was considered significant by both the employees involvedand the company. The best practice to boost the input of employees in acompany is the reprimand followed by an encouragement policy. It recalled that a worker's performancealso depends on their relationship with the company, so it is also essential for a company to motivate and Groom an employee to get the best results. Nuning Nurna Dewia and Rudi Wibowo (2020) show that Leadership Style, Organizational Culture, empowerment factors, and Motivation simultaneously influence the performance of employees.

Empowerment is the authority given by management toits employees to act independently to meet expectations. In the era of theunprecedented pandemic, there is a need foremployee empowerment to take quick decisions and act quickly to any changes in the environment. An empowering organization emphasizes autonomy, proper information sharing, individual participation and teamwork to achieve organizational success. To achieve empowerment in the organization, the executives must ensure that employees have the right mix of Information, knowledge, power, andrewards to work more enthusiastically. Theimpact of empowerment on employee performance is enormous, and it is a widelystudied subject by scholars. Jay A. Congerand Rabindra N.Kanungo(1988) find empowerment as an emerging construct used by theorists to explain organizational effectiveness. Archana and DrM.P.Singh (2018) find that empowerment is the process of sharing power with employees. The empowerment of employees depends on mutual trust and respect. Employee involvement in the decision-making helps the organization build the corporation between them. A distinction was made between organizational empowerment, a bundle of HRM activities, and psychological empowerment by Ruta Kazlauskaite, Ilona Buciuniene, and Linas Turauskasas(2011). Organizational empowerment was undoubtedly related to psychological 


\section{International Advanced Research Journal in Science, Engineering and Technology \\ Impact Factor $7.105 \div$ Vol. 9, Issue 1, January 2022 \\ DOI: 10.17148/IARJSET.2022.9148}

empowerment, job satisfaction, and Affective Commitment. Psychological empowerment and affective commitmentwere found to mediate the impact of organizational empowerment on customer-oriented behaviour. Food processing in India was started as a family profession. V.P Sriraman \& DrL.Rathakrishnan (2008) finds that the food processing sector in the country, with its vast potential, has emerged as one of theprimary drivers of economic growth and is often hailed as a sunrise industry. The organized food industry was started for the British officers and settlers. Despite the lackof training, they prepared quality foods likepickles, papads, fried, roasted, and puffed cereals for local consumptions. During the second world war, the number of these units multiplied to satisfy the needs of the troops. The products produced were bread, biscuits, jams, squashes, andsyrups. It is impossible to acquire adequategrowth in the value-added food processing sector without establishing well-organized facilities identified only during the eighties.Processed foods provide a good export opportunity and generate employment inrural areas to restrict population migration to cities. Dr V.R.Palanivelu \& A.Apdhul Kathar (2016) conclude that though many good dynamics support the potential forgrowth of this industry, there are still somesignificant constraints that, if not addressedsooner, can impede the growth prospects ofthe Food Processing Industry in India.

Kerala has always been a 'leader state' in food processing. A state with a food processing sector formed a backbone towards making significant contributions tofood exports since independence. Though small in size, Kerala is a very fertile land with a diverse range of crops providingnumerous opportunities for value addition. The food processing industry is gaining vastimportance with emerging markets andtechnologies. The research performed in the food industry is deficient compared to its contributions. In their article regarding MSME, A. Sathish and Dr S. Rajamohan (2019) reveal that the Micro, Small, and Medium Enterprises (MSME) sector has emerged as complementary for large industries as ancillary units. MSME food industries in Kerala have an excellent capacity to grow and contribute to the Kerala financial system. It is enormously contributing to the enhancement of the socio-economic profile of the state by providing extensive employment opportunities at a lower cost comparativelythan large industries. It is necessary to support the MSMEs, educate and give power to them to make optimum utilization of the resources, both human and economic, be informed of the latest developments taking place globally, and help acquire skills necessary to keep pace with the global developments. Rajeswari G (2019) observed that most of these enterprises are unaware and do not understand how they can benefit from them.

The management seeks new techniques and methods to improve the performance of their employees with minimum cost and maximum utilization of resources. Several factors affect employee performance, and in this article, we study the impact of employee empowerment on employee performance. The empirical study conducted by Shilpa N.C and Dr Amulya M (2019) finds that the value addition in the food processing industry hastremendously amplified over the years. MrsCaral Lopes, Ms Dhara Kachalia (2016) find that employees should adopt new coping strategies to maintain good physicaland mental conditions and improve productivity. This study was conducted amid a pandemic that severely affected our economy, which was unexpected. Covid '19 and its impact onthe economy is a subject that needs more depth investigations individually. Shaik Rubeena \& Rafia Naz (2020) finds that tosupport the health of their employees, companies have tried various tools and technological aspects during the crisis. In Kerala, Covid 19 on food industries are innumerable, to overcome this situation andbuilding a new healthy market is the challengethe management side faces. Most food manufacturing industries, especially MSME firms, face a severe crisis on the financial side. The manufacturing cost is increasing day by day, but raising the priceof their products is dreadful due to the poormarket conditions. Repeatedly Kerala facednumerous tragic situations in the past yearslike Demonitisation, First and second Flood, and now in Covid 19. The purchasing powerof ordinary people is decreased due to the financial scenario, and at the same time, MSME food manufacturing units facecutthroat competition from MNC.'

\section{OBJECTIVES OF THE STUDY}

To identify the level of motivation among employees, which should enhance their level of performance.

To examine the degree to which employees feel empowered in the food manufacturing industries in Kerala.

To evaluate the relationship betweenemployee empowerment and employee performance in the foodmanufacturing industries in Kerala.

To suggest ways to improve the performance of employees in the food manufacturing industries in Kerala.

\section{RESEARCH HYPOTHESIS}

The employees in the foodmanufacturing industry in Kerala are not motivated to enhance their performance The employees in the foodmanufacturing industry in Kerala arenot sufficiently empowered in their roles. There is no significant relationship between empowerment and improvement in performance in the food manufacturing industry inKerala 


\section{International Advanced Research Journal in Science, Engineering and Technology \\ Impact Factor 7.105 $\doteqdot$ Vol. 9, Issue 1, January 2022 \\ DOI: 10.17148/IARJSET.2022.9148 \\ LITERATURE REVIEW}

Employees are the force that drives a company forward. So it should come as no surprise that the daily performance of the workforce hugely influences the success orfailure of a business. Senait Laike (2017) study results have provided necessary implications on the relationship between organizational culture and performance management practices. Sara R. Colorosa \& Carole J. Makela (2016) find that the managers have successfully created an environment that empowers all employees to be successful and performtheir jobs using their skills and strengths; they stopped focusing on the behavioursand started focusing on the measurable outcomes. In this pandemic time,businesses must find ways to maintain and bring out the best performance from their employees. The current appraisal method isfragile and inappropriate in Leila Najafi, Yadollah Hamidi, Sudabeh Vatankhah, Abdolhosein Punraj (2010). Therefore, it seems necessary to reform this critical process both in content and performance.

Human history has witnessed great rupturesthat have affected all societies in different periods. Depressions and crises such as wars, natural disasters (famine, earthquake,fire, climate irregularities, etc.), epidemics,economic emergency, terrorist activities, and political disputes have been indicated as the Causes of these significant ruptures. They have caused radical changes by affecting the economy of allsocieties. Unfortunately, the currentsituation we are experiencing today, which the Covid-'19 epidemic has caused, is a global depression, leading to large-scale ruptures. Beyza Erer (2021) reveals that when the national and international literature was examined, no study to address the performance of employees and the fear of Covid-19. Wadi B Alonaz (2020) suggests that healthcare providers' empathic environment may significantly increase employeeperformance. B Suresh Lal, Phalguni Sachdeva, Simran, Tanu Mittal (2020)finds the Coronavirus pandemic, and the following restrictions on mobility have heightened this crucial sector's vulnerabilities. The research findings from Mahmud Hamid and Dr Sazali Abdul Wahab (2020) explained that COVID-19 and employees' reactions to changessignificantly negatively impact employees' performance. These 'new normal' changes negatively affected employees' work concentration, communication, and concentration on work significantly. Galih Fajar Muttaqin1, Muhammad Taqi, Bustanul Arifin (2020) studied this andsuggested that Increased innovation, job satisfaction, and supervisory supervision are needed to improve the job performanceof companies during this pandemic.Indranil Bose (2018) has suggested thefundamental goal of HR in an organization.The research conducted in partnership withMicrosoft and the Boston Consulting Group recommends establishing traditionalmeans of connecting with the team and maintaining those routines, even amidchange and disruption.

The outcome from Henry Ongori (2009) article indicates that employee empowerment is essential in uncertainty to enable the organization to respond quickly to any changes in the environment and reduce employee turnover. Munish and Rachna Agarwal (2017) indicate that goodtraining \& development, compensation structures, autonomy, quality of work-life, work policies, and arrangements will lead the managers and management to a new dimension with a holistic approach in the field of employee retention \& engagement.

Empowering employees is a culture. It takesan increase in trust, clear communication, and strategic delegation. Sambil Charles Mukwakungu, Charles Mbohwa, and Sihle Mankazana (2018) show a significant employee empowermentlevel. Dean Tjosvold and Haifa Sun (2005) indicate that managers' perspective toward power, not just power itself, dramatically affects how power is used andhow managers are empowered. Tahira Michelle Probst (2005) examined the effectiveness of increased organizational participative decision-making in reducing the negative consequences of job insecurity. Harpreet Singh and Dr Salvatore Fawa (2019) depict that employee participation indecision-making has positively affected employee attitude, commitment, and productivity, even on the managers'efficiency. Empowered employees are so close to issues and problems that require resolution facilitating a decrease inresponse time. Faced with a problem, people close to it have a natural affinity for it and a definitive reason to findsolutions rapidly-it aids their work, makingtheir time more accessible and more productive. Krishnaveni. R and Monica. R (2018) reveals that HRM methods, namely empowerment, competence development practice, recognition, and work engagement, have emerged asprominent predictors of employeeperformance. Sakib Imran Khan, Dr Keith Macky, and Dr Erling Rasmussen (2011) find the critical rationales behind their organizations' adoption of devolution strategy were to empower the line managers, make them more responsible, achieve a strategic approach to HR, and leverage linemanagers' proximity to the employees. Behdokht Rekabdar, D. Kane, C. Kwantes, and G. Chung-Yan (2015) highlight the importance of employee felt trustworthiness. Aniket. M. Kamble and Dr R. Gopal (2014) provide suggestions and practical guides to the management of thecompanies to promote the improvement of their companies and workers' performance for making decisions related to their interests. Kelly Tee Pei Leng (2013) provides insights into developing a taxonomy of good feedback practices by considering the views of the giver and the receiver of written feedback. Isabel Buila, Eva Martínezb, and Jorge Matute (2018) show that identification andengagement fully mediate the relationship between transformational leadership and organizational citizenship behaviours, whereas engagement partially mediates the link between transformational leadership and job performance. Mohand Tuffaha (2020) indicates that knowledge management,Information and communication technology, employee empowerment, innovation and creativity, and organization culture significantly impact employee performance. Dr Salini BNair and Shitha. M. S (2018) suggests that organizations should take care of the working conditions such as maintenance, temperature, lighting becausethe majority 


\section{International Advanced Research Journal in Science, Engineering and Technology \\ Impact Factor 7.105 Vol. 9, Issue 1, January 2022 \\ DOI: 10.17148/IARJSET.2022.9148}

of the employees are only moderately satisfied with working conditions.

Dr Rajesh Rathore (2015) Indicate that raising the level of employee performance may be attained by investigating and analyzing employee empowerment, considering the diagnosis and analysis of the requirements necessary to apply employee empowerment, such as organizational culture, participation, effective communication, continuoustraining, incentives system, managerial trust, clarity of role, executive support, getting the required information and teamwork. Empowered employees working without continual oversight from a manager or supervisor tend to feel more respected. Artificial obstacles to the progress of tasks are removed when employees no longerneed their supervisor's approval to move from one stage to the next. E. Ashraf (2020) revealed that employee empowerment has a direct and significant impact on employee satisfaction. This helpsproductivity and profitability per employeeimprove accordingly. Suharno Pawirosumarto, Purwanto KatijanSarjana, and Rachmad Gunawan (2016) show that work environment, leadership style, and organizational culture firmly and significantly impact job satisfaction only the leadership style positively and significantly affects employee performance.Seung-Bum Yang and Sang Ok Choi (2008) identified four dimensions of employee empowerment: autonomy, responsibility, Information, and creativity.Sarra Berries, Mehrez Chaher, KarimBen Yahia (2014) reveal that this managerial practice increases employees'trust, positively affecting innovation and organizational performance. Ruta Kazlauskaite, Ilona Buciuniene, and Linas Turauskas (2011) reveal that organizational empowerment was positively related to psychological, job satisfaction, and affective commitment.Anitha J (2013) studies also reveal that theworking environment should comprise a good culture, working with a good team, a good boss, good physical surroundings, jobsecurity, a sustainable compensation package, and availability of food and drink in the workplace. All these factors in the workplace could increase workers' morale and contribute to increased manufacturing productivity. Sylvie Guerrero, DenisChênevert, Christian Vandenberghe,Michel Tremblay, and Ahmed Khalil BenAyed (2018) shows that positive customer feedback can substitute managers'leadership in helping frontline employees feel more in control of their work and psychologically empowered.

Empowered employees working without continual oversight from a manager or supervisors tend to feel more respected. Artificial obstacles to the progress of tasks are removed when employees no longerneed their supervisor's approval to move from one stage to the next. Anastasios, D. Diamantidis Prodromos Chatzoglou (2018) suggest that managers should dynamically support employees' job-relatedactions. This support should be given to their employees personally and by improving both organizational climate and job environment, directly and indirectly, affecting their job performance levels.Darren James Elding (2018) found that performance was significant in predicting satisfaction with all individual job characteristics except 'Feedback from Supervisors,' 'Social Relations,' and 'Workload.' Tayo Emmanuel (2018) concluded that a total rewards system is vital in every financial industry. Since employers are looking for talented people, they must produce the types of rewards that will meetemployees' needs to retain them for the longterm. Aqeel Ahmed Soomro, Robert J. Breitenecker, and Syed Afzal MoshadiShah (2017) indicate that work-life balancepositively impacts employee performance. Shadi Habis Abualoush, Abdallah Mishael Obeidat, Ali Tarhini, Ra'edMasa'deh, and Ali AlBadi (2017)indicated that knowledge management and information systems positively and significantly affect

Employees' Empowerment. The latter impacts Employees' Performance as well. Sergio Fernandez and Bloomington TimaMoldogaziev (2013) suggest that using empowerment practices to stimulate innovation does not result in immediate gains in performance. Managers adopting such an approach must be patient for the organizational changes sparked by empowerment to bear fruit in performance improvements. Vineethan. T (2018) suggests that the joint efforts of all the various agencies in the MSME sector can bring a sustainable contribution to national income, employment, and exports. Kevin Baird, Amy Tung, and Sophia Su (2020) provide an empirical insight into the mediating role of the quality of performanceappraisal systems on the association between employee empowerment andbusiness unit performance. This helps productivity and profitability per employeeimprove accordingly.

Dr Silbert Jose S. V. \& Mr Bijin Philip (2019) suggest that if employees' empowerment and recognition increase, their motivation to work improve, and their accomplishments and organizational performance increase.M M Bagali(2015) highlights how an organization could establish an outstandingorganization and thus create a place to work. Sarra Berraies, Rached Chtioui,and Mehrez Chaher (2019) offer interesting insights to bankers by providingthem with tools to improve their customers'relationships. Kuranchie-Mensah,Elizabeth Boye, Amponsah-Tawiah, and Kwesi (2016) observed that management must ensure that employees are well due tothe risk factors associated with the industrymotivated to curb the rate at which employees embark on industrial unrest, affecting performance. Cecily Shibi Netto (2019) reveals the problems faced by the industry in Kerala, which range from the procurement of raw materials to the export of finished products. Taylor and Francis (2016) supported the universalistic theory of strategic human resource management, which believes that any organization can adopt a distinctive set of HR practices, which results in improved performance. Mohammed Kasim C (2019) suggests thata high vulnerability in food availability in the state calls for urgent policy attention onthe production front.

Shilpa N.C. and Dr Amulya M. (2019) attempts to analyze the growth of the food processing industry in terms of employmentand value addition. Emiko Fukase, Will Martin (2020) studies economic growthand its impact on the food demand andsupply chain. Dr Deeja. S (2017) finds thatthe food processing industry holds tremendous opportunities for significant investments. Dhayita Rukti Tanaya and Fandis Ekyawan (2020), presented in this paper, has essential points 


\section{International Advanced Research Journal in Science, Engineering and Technology \\ Impact Factor $7.105 \div$ Vol. 9, Issue 1, January 2022 \\ DOI: 10.17148/IARJSET.2022.9148}

to deeply understand the existing MSMEsempowerment strategy in Indonesiaimplemented by BMC, the strategy shifts during the pandemic, and recommendationsfor strategic improvements.

María de la Cruz del Río-Rama, MarthaRíos-Manríquez, José Álvarez-García and María Dolores Sánchez-Fernández (2020) clarify that although information is necessary to train human capital, cognitive variables are more important in human capital empowerment. Brian Daly(2017)suggests that As the organization becomes more dependent on its employees' knowledge, their management becomescritical for the line managers. Laurian Unnevehr (2019) also allows comparisons with the manufacturing industry and an understanding of the industry as asignificant economic contributor to regionaleconomies. This focus on the food and beverage industry provides new insights regarding the industry's multiple roles, including the industry's contributions in meeting emerging consumer demands and responding to evolving public policy. Ms Shelly and Dr Kuldip Kaur (2015) Basedon the study, this paper's findings and conclusion are that the food processing industry is enormously significant for India's development. Peter T. Coleman (2014) speaks to the potential causal role ofimplicit power theories in shaping managers' responses to empowerment initiatives. When employees are empowered withresponsibility, managers become freed to concentrate on strategy and the bigger picture. Instead of becoming enmeshed withday-to-day decision-making, managers canconcentrate on strategic objectives, project planning, professional developmentcustomer-centric activities. MelissaIntindola, Judith Y. Weisinger, Philip Benson, and Thomas Pittz (2017) highlight the importance of a multi-level approach consisting of individual, human resource management (HRM) team, and organizational contingency factors when considering the efficacy of HRdevolvement efforts. Brijesh Singh, Rakesh Narain, and R.C. Yadav (2012) suggest that financial assistance through banks needs to be improved to adopt technological changes and expand to compete in present market conditions.Pravakar Sahoo and Ashwani (2020) suggest that the economy is heading towards a recession, and the situation demands systematic, welltargeted, andaggressive fiscal-monetary stimulusmeasures.

Davinder Singh, J.S. Khamba, and Tarun Nanda (2018) study has explored various problems and challenges faced by Indian MSMEs in the competitive environment and the technology innovationinitiatives for obtaining and maintaining their manufacturing performance. Issifu Amadu Abdulai and AdinanBahahudeen Shafiwu (2014) indicated thatdecisionmaking becomes easy when employees participate. This system creates a good working environment, increases commitment and satisfaction on decisions taken, and increases employee morale since they feel recognized as part ofthe organization's teaming and the direct consequence of all this improvedproductivity. Marjolein de Kort, R. F. Poell, and Dr M.J. D. Schalk (2016) analyses showed that employees with a high work-life conflict were less engaged in their work and were more likely to participate in employee development activities. Iqra Iqbal, Muhammad Zia-ud-Din, Arifa Arif, Mahmood Raza, and Zunaira Ishtiaq (2017) find that employee engagement, work-life balance, and employee cynicism are highly correlated. Arvind Mallik, Lakshmi Mallik, and Keerthi DS (2019), to drive their organizations to peak performance, managers and supervisorsmust put out front the human face of their organization. A significant reason employee involvementhas grown because it has been shown to increase employee commitment to their organizations. By involving employees actively in decision-making, company leaders affirm the value of their employees.Employees naturally develop deeper commitments to organizational and departmental objectives when they help setthem and are involved in achieving them byoffering input and making decisions that affect success. Employees become more involved in organizational strategy with the greater involvement engendered by their increased responsibility. They Begin to look at colleagues and customers differently and their commitment to the company and its future growth. Malik Shaharyar, Mushtaq Ahmad Baloch,Muhammad Ahsan Tariq, Seemal Mushtaq, and Adeel Mushtaq (2014) show performance appraisal's impact on theemployee's performance. The management or the line managers set the benchmark performance so that it helps in evaluating the performance of the employees individually or collectively as a group. Florence-K. Muindi (2011) indicates that a significantly strong positive correlationexists between job satisfaction and participation in decision-making. Bhanu Priya and Dr Satish Soni (2017) found a significant relationship betweendemographic variables like job role, gender,age, education, and impact of occupational should adopt new coping strategies to improve the bank's better level.

Ayman Zakaria Najeeb and Dr Ali FalahDalain (2013) depict that any company's growth is now highly dependable on the use of Information and communication technology specifically. Lisa Olsson (2012) thesis examinesleadership and creativity in research. Artsem Lashchonau and Ileana Androniu Pardal Monteiro (2015) show that appraisal satisfaction and proceduralfairness are significantly positively related directly and indirectly to employees' motivation, while perceived accuracyimpacts employees' motivation just indirectly. Satisfied employees lead tosatisfied customers. Such commitment alsoleads to decreased staff turnover and reduced cost of hiring and training. Humanresources practitioners in a learningorganization can greatly promote employees' job involvement and improve performance. Besides developing policies to foster employee engagement atwork, managers need to pay careful attention to the recruitment, training, reward, and recognition dimensions that affect involvement behaviour-employee'sjob involvement and satisfaction in a learning organization by DeepanjanaVarshney (2019). The quantitative study results showed that serving and mentoring others positively affects employee performance and satisfaction, while coaching others only affects performance. Monitoring others didnot show any relationship with employee effectiveness. Empowering employees invigorates leadership by removing the stress of day-to-day management responsibilities. It can be said that employeeempowerment 


\section{International Advanced Research Journal in Science, Engineering and Technology \\ Impact Factor $7.105 \div$ Vol. 9, Issue 1, January 2022 \\ DOI: 10.17148/IARJSET.2022.9148}

and organizational stress areimportant concepts affecting working life. The fact that employees do not have enough components of employee empowerment increases their stress levels by Mustafa Demirkiran, Serap taşkaya 2016. Caral Lopes and Dhara Kachalia (2016) As a result, the level of stress faced by the employees in the banking sector is also overgrowing. Gholamreza Jandaghi, Ali Mokhles, and Hamid Bahrami (2011) explore job security's impact on employees'commitment and job satisfaction in Qom municipalities. Anees Ullah Karamat (2013) aimed to determine the impact of leadership behaviours on organizational performance. Mary Christina D and Kanishka. K (2014) deals with stress and its impact on productivity. Steven D.Raymer and Jeanette Cleveland (2014) results showed that leadership did not affectresponsibility or empowerment, while culture significantly affected commitment and empowerment. Shaun Macgregor Gordon (2016)addresses creativity and innovation literature and explores the necessity for creativity in implementing service innovations. Additionally, people own the responsibility given to them and the manager/employee relationship benefits accordingly. Public relations specialists, employers, human relations staff, and managers face problems withemployee morale. Hundreds of organizations and companies have problems with morale, but few have found ways to solve them. Often, it is a lack of understanding between employees and supervisors by Allison Rohner (1999).

\section{RESEARCH FRAMEWORK AND RESEARCHMETHODOLOGY}

The present research can be considered exploratory as this research has attempted toget an insight into the research area, onwhich no significant work has been found inthe context of food manufacturing industries in Kerala. For this research, a mixed-methods approach has been used as facts and Information from secondary sources have been collected, and data in theform of respondents' feedback have been gathered through structured andunstructured questionnaires. Moreover, the present research can also be classified as inductive and applied research. It is inductive as the present study intends to logically infer and establish a relationship between employee empowerment andemployee performance based on observations. Also, it is an applied work, asthey attempt to investigate practicalproblems and issues on the concept and theories on employee empowerment andemployee performance and their relationship has been made. From the research philosophy perspective, the present research has followed epistemology as the research philosophy in the interpretive paradigm. As mentioned earlier, the present research isbased on primary and secondary datacollected from respective sources. A surveywas conducted through the structured questionnaire to collect primary data, and secondary data were collected from the reports of the various journals and books published by other third-partyorganizations. A total of 21 questions were asked through the questionnaire, and the validity of the questionnaire was tested. Thepopulation size for this research is approximated at around 600 employees offive food manufacturing industries in Kerala. With a margin of error of $12.61 \%$ and a confidence level of $95 \%$, the researchtargeted a sample size of 110 respondents with an estimated response rate of $100 \%$. However, the same was sent toapproximately 110 employees working in Kerala's five food manufacturing industries.Responses were registered with the help of the Likert scale and codes associated with each response. While collecting feedback through a questionnaire, simple random sampling without replacement technique was used in each company. A more detailedanalysis of the respondents' profiles shows that $33 \%$ are factory workers. $55 \%$ of respondents were middle managers, $7 \%$ were managers, and $5 \%$ were senior managers. The age group of respondents - 91.6\% belonged to the age group $21-30 \mathrm{yrs}$, the rest were 31-40 yrs, and less than $1 \%$ belonged to the age group $41-50$ yrs andabove 50 yrs. Years of experience - $47 \%$ ofrespondents had 3 to 5 years of work experience, $29 \%$ had one to three years of experience, $14 \%$ had less than one yearexperience, and the rest had more than fiveyears of work experience. $60 \%$ of the respondents were male, and the rest, $40 \%$, were female.

\section{DATA ANALYSIS}

Descriptive analysis has been carried out to describe the respondents' profile and response patterns. Standard statistical tools such as mean, median, mode, standard deviation, standard variance, one-sample t-test, and correlation coefficient have also been used to test the research hypotheses.Table 1 depicts the respective questions related to each of the research objectives.

\begin{tabular}{|l|l|l|}
\hline Table 1 Research objectives and research questions \\
\hline $\begin{array}{l}\text { Research } \\
\text { objectiveNo. }\end{array}$ & Research objective statement & $\begin{array}{l}\text { Related questions (Refer } \\
\text { questionnaire) }\end{array}$ \\
\hline 1 & $\begin{array}{l}\text { To identify the level of motivation among employees } \\
\text { should enhance their level ofperformance }\end{array}$ & Question 1- Question 3 \\
\hline 2 & $\begin{array}{l}\text { To examine the degree to which employees feelempowered in } \\
\text { the food manufacturing industries } \\
\text { in Kerala }\end{array}$ & Question 4- Question 11 \\
\hline & To evaluate the relationship between employee empowerment and & \\
\hline
\end{tabular}




\section{International Advanced Research Journal in Science, Engineering and Technology \\ Impact Factor 7.105 Vol. 9, Issue 1, January 2022 \\ DOI: $10.17148 /$ IARJSET.2022.9148}

\begin{tabular}{|l|l|l|}
\hline 3 & $\begin{array}{l}\text { employee performance in the food manufacturing industries in } \\
\text { Kerala }\end{array}$ & \\
\hline 4 & $\begin{array}{l}\text { To suggest ways to improve the performance of employees in the } \\
\text { food manufacturing industries inKerala }\end{array}$ & Question 21 \\
\hline
\end{tabular}

Four research objectives are identified, and twenty-one questions are identified to prepare the questionnaire. The questions are prepared based on different articles and in-depth studies related to the subject. From Table 1, it is seen that specific questions were prepared to accomplish different research objectives.

\begin{tabular}{|c|c|c|c|c|c|}
\hline ISSUES & Mean & Median & Mode & $\begin{array}{l}\text { Std. } \\
\text { Deviation }\end{array}$ & Variance \\
\hline Encouragement from supervisor & 3.33 & 3 & 3 & 0.86 & 0.74 \\
\hline Positive morale & 3.54 & 4 & 4 & 0.87 & 0.76 \\
\hline $\begin{array}{l}\text { Overall job satisfaction in the current } \\
\text { market condition }\end{array}$ & 3.51 & 4 & 4 & 0.96 & 0.91 \\
\hline
\end{tabular}

Table 2 depicts the present level of motivation among the employees of the food manufacturing industries in Kerala. It is found that the average mean of responses from question 1 to question 3 has remained 3.46, which is above average on a 5-point Likert scale.However, the standard deviation and standard variance calculated on each response against the first three questions are moderate. Regarding positive morale, respondents have given relatively positive feedback, and median and mode scores of 4 represent these phenomena occurring in response patterns. The standard deviation and standard variance showmoderate inconsistency in responses. The first three questions asked to identify the level of motivation among employees, and the results indicate that motivation level is above average, but it is not sufficient to get the maximum result.

\begin{tabular}{|c|c|c|c|c|c|}
\hline ISSUES & Mean & Median & Mode & $\begin{array}{l}\text { Std. } \\
\text { Deviation }\end{array}$ & Variance \\
\hline Level of superior influence & 3.05 & 3 & 3 & 1.06 & 1.12 \\
\hline Control over job & 3.91 & 4 & 4 & 0.82 & 0.67 \\
\hline Group potency & 3.83 & 4 & 4 & 0.81 & 0.66 \\
\hline Self-determination & 3.30 & 3 & 3 & 1.13 & 1.28 \\
\hline Impact creation & 3.44 & 4 & 4 & 0.90 & 0.82 \\
\hline Competence building & 3.38 & 4 & 4 & 0.87 & 0.75 \\
\hline Meaningfulness in work & 3.25 & 3 & 4 & 1.07 & 1.15 \\
\hline Autonomy in decision making & 3.21 & 3 & 4 & 1.08 & 1.16 \\
\hline
\end{tabular}

The response pattern shows that control over job is moderately high, and a median andmode of 4 represents the most frequently occurring response. From Table 3, it is found that the highest positive feedback has been registered control over the job(Q5), which is calculated through mean as 3.91, and median and mode represent the higher frequency of occurrence of such responses.

Standard deviation and standard variance also show more consistent feedback from the respondents' side. Though onthe issue of self-determination, respondents seem to be highly inconsistent. The response pattern reveals that the employees from the food manufacturing industry feel empowered. The degree shown in the result column requires more empowering activities from the management side. 


\section{International Advanced Research Journal in Science, Engineering and Technology \\ Impact Factor 7.105 Vol. 9, Issue 1, January 2022 \\ DOI: 10.17148/IARJSET.2022.9148}

\begin{tabular}{|c|c|c|c|c|c|}
\hline ISSUES & Mean & Median & Mode & $\begin{array}{l}\text { Std. } \\
\text { Deviation }\end{array}$ & Variance \\
\hline Autonomy to take decisions & 2.70 & 2 & 2 & 0.81 & 0.65 \\
\hline Meaningfulness of work & 3.31 & 3 & 4 & 0.98 & 0.97 \\
\hline Impact of work & 3.16 & 3 & 4 & 0.99 & 0.98 \\
\hline Competence to do the work & 2.75 & 3 & 3 & 0.58 & 0.33 \\
\hline Self-determination to take decision & 2.87 & 3 & 3 & 0.69 & 0.48 \\
\hline Resources used & 2.75 & 3 & 3 & 0.71 & 0.50 \\
\hline Supervisors' involvement & 2.66 & 3 & 2 & 0.72 & 0.52 \\
\hline Collective belief within the group & 2.77 & 3 & 2 & 0.82 & 0.67 \\
\hline Overall organizational culture & 2.83 & 3 & 3 & 0.80 & 0.64 \\
\hline
\end{tabular}

Table 4 shows that the mean score of all the questions listed is above 2.86, representing that most employees accept the role of all these environmental factors in improving their performance at work. The median and mean also depict a similar opinion of the employee. Where 3 is the most often selected option. The standard deviation and standard variance showrelatively moderate consistency in opinions. It is also found that the Meaningfulness of work remainedthe most preferred chosen factor, which according to the pattern of opinions, influences mostof the performance improvements. Superiors' involvement has shown a minor performance. The employees are not fully aware of the empowerment factors which affect their performance level.

\begin{tabular}{|c|c|c|c|}
\hline Factors & Percentage & $\begin{array}{l}\text { Cumulative } \\
\text { percentage }\end{array}$ & Rank \\
\hline Impact of work & $19 \%$ & $19 \%$ & 1 \\
\hline Meaningfulness of work & $17 \%$ & $36 \%$ & 2 \\
\hline Resources & $15 \%$ & $51 \%$ & 3 \\
\hline Group potency & $15 \%$ & $66 \%$ & 4 \\
\hline Autonomy to make decisions & $14 \%$ & $80 \%$ & 5 \\
\hline Competence & $10 \%$ & $90 \%$ & 6 \\
\hline Impact of work & $19 \%$ & $19 \%$ & 1 \\
\hline Meaningfulness of work & $17 \%$ & $36 \%$ & 2 \\
\hline Resources & $15 \%$ & $51 \%$ & 3 \\
\hline
\end{tabular}

According to the above observation, it is found that impact of work remained most favoured factor to improve the performance of employees. In contrast, organizational culture has been identified by the least number of respondents as the most preferred factor of improving performance at the workplace.

\section{Testing the Hypothesis}

Three hypotheses have been formulated for the present research. Statistical tools like one sample t-test and correlation coefficient have been used to test these null hypotheses.

Null Hypotheses 1: The employees in the food manufacturing industry in Kerala are not motivated to enhance their performance.

One sample t-test analysis was conducted to test the null hypothesis. For this testing,the significance level is set at 0.10 . Feedback on three questions (Q1, Q2, and Q3) has been considered for testing this null hypothesis. These questions were asked to get feedback on Encouragement from the supervisor (Question 1), Positive morale Question 2), and Overall job satisfaction in the current market condition (Question 3) have been used for testing hypothesis 1 (Table 6). 


\section{International Advanced Research Journal in Science, Engineering and Technology \\ Impact Factor 7.105 Vol. 9, Issue 1, January 2022 \\ DOI: 10.17148/IARJSET.2022.9148}

Table 6. One-Sample T-Test Analysis for Testing of Null Hypothesis 1

\begin{tabular}{|c|c|c|c|c|c|c|}
\hline \multicolumn{7}{|c|}{ One-Sample Test } \\
\hline & \multicolumn{6}{|c|}{ Test Value $=3.46$} \\
\hline & \multirow{2}{*}{$\mathrm{T}$} & \multicolumn{2}{|l|}{ Significance } & \multirow{2}{*}{$\begin{array}{l}\text { Mean } \\
\text { Difference }\end{array}$} & \multicolumn{2}{|c|}{$\begin{array}{l}95 \% \text { Confidence Interval of } \\
\text { the Difference }\end{array}$} \\
\hline & & One-Sided $\mathrm{p}$ & $\begin{array}{l}\text { Two-Sided } \\
\text { p }\end{array}$ & & Lower & Upper \\
\hline Q1 & -1.62 & 0.05 & 0.11 & -0.13 & -0.29 & 0.03 \\
\hline Q2 & 0.92 & 0.18 & 0.36 & 0.08 & -0.09 & 0.24 \\
\hline Q3 & 0.54 & 0.30 & 0.59 & 0.05 & -0.13 & 0.23 \\
\hline
\end{tabular}

Null Hypothesis 2: The employees in the food manufacturing industry in Kerala are not sufficiently empowered in their roles. From Table 7, it is found that the P one-tail value for allthe three factors is greater than the significance level set. Therefore, the null hypothesis is notrejected. To test this null hypothesis one-sample t-test is used; the significance level for the test has also been set at 0.10 . Table 7 represents all the different aspects of employee empowerment identified in the literature review and incorporated in the questionnaire. Table 7. One-Sample T-Test Analysis for Testing of Null Hypothesis 2

\begin{tabular}{|c|c|c|c|c|c|c|}
\hline \multicolumn{7}{|c|}{ One-Sample Test } \\
\hline & \multicolumn{6}{|c|}{ Test Value $=3.42$} \\
\hline & \multirow{2}{*}{$\mathrm{T}$} & \multicolumn{2}{|c|}{ Significance } & \multirow{2}{*}{$\begin{array}{l}\text { Mean } \\
\text { Difference }\end{array}$} & \multicolumn{2}{|c|}{$\begin{array}{l}95 \% \text { Confidence Interval } \\
\text { of the Difference }\end{array}$} \\
\hline & & $\begin{array}{l}\text { One-Sided } \\
\mathrm{p}\end{array}$ & $\begin{array}{l}\text { Two-Sided } \\
\text { p }\end{array}$ & & Lower & Upper \\
\hline $\mathrm{Q} 4$ & -3.63 & 0.00 & 0.00 & -0.37 & -0.57 & -0.17 \\
\hline Q5 & 6.26 & 0.00 & 0.00 & 0.49 & 0.33 & 0.64 \\
\hline Q6 & 5.27 & 0.00 & 0.00 & 0.41 & 0.25 & 0.56 \\
\hline Q7 & -1.11 & 0.13 & 0.27 & -0.12 & -0.33 & 0.09 \\
\hline Q8 & 0.19 & 0.42 & 0.85 & 0.02 & -0.15 & 0.19 \\
\hline Q9 & -0.46 & 0.32 & 0.65 & -0.04 & -0.20 & 0.13 \\
\hline Q10 & -1.62 & 0.05 & 0.11 & -0.17 & -0.37 & 0.04 \\
\hline Q11 & -2.06 & 0.02 & 0.04 & -0.21 & -0.41 & -0.01 \\
\hline
\end{tabular}

From the above table (table 7), it is observed that the value for $\mathrm{P}$ one-tail is more significant than 0.10 across all the different factors. Therefore, it can be concluded that null hypothesis 2 is not rejected.

Null hypothesis 3: There is no significant relationship between empowerment andperformance improvement in Kerala's food manufacturing industry. The relationship between employee empowerment factors identified through literature review and incorporated in the questionnaire (such as autonomy, Meaningfulness, impact, competence, etc.) and employee performance has been individually tested (Table 8). The correlation coefficient technique has been used to test the last and final hypothesis.

\begin{tabular}{|l|l|}
\hline \multicolumn{2}{|l|}{ Table 8. Correlation Coefficient for Testing Null Hypothesis 3 } \\
\hline Employee Empowerment Factors & Correlation Coefficient \\
\hline Autonomy & 0.477 \\
\hline Meaningfulness & 0.13 \\
\hline Impact & 0.058 \\
\hline Competence & 0.379 \\
\hline Self-Determination & 0.321 \\
\hline Resources and Specialization & 0.399 \\
\hline Supervisor's Influence & 0.343 \\
\hline Group Potency & 0.326 \\
\hline Organizational Culture & 0.533 \\
\hline
\end{tabular}

It can be observed from the above table that all the factors individually show a correlation coefficient, which is approximately greater than 0.3 , which indicates that there is a positive relationship, as the values are closer to +1 . The correlation between organizational culture andemployee performance and autonomy and employee performance seems to be highest compared to the other factors. Hence based on this observation, the null hypothesis stands notrejected. 


\section{International Advanced Research Journal in Science, Engineering and Technology \\ Impact Factor $7.105 \div$ Vol. 9, Issue 1, January 2022 \\ DOI: 10.17148/IARJSET.2022.9148 \\ FINDINGS AND OBSERVATIONS}

The following findings can be identified from the data analysis, Literature review, observations, and testing of null hypotheses. The overall motivation level of the employees seems to be moderate in the food manufacturing industry in Kerala, and the exact requirements to be improved to a great extent as per the study. The same was reflected via

testing the null hypothesis, where findings come out as the lack of acceptance of the employees' empowerment phenomenon. Different phenomena have been noted regarding the degree to which employees feel empowered in the

\begin{tabular}{|l|l|l|l|}
\hline Table 9. Brief Overview on Testing of Null Hypotheses \\
\hline $\begin{array}{l}\text { Null } \\
\text { Hypothesis }\end{array}$ & $\begin{array}{l}\text { Null hypothesis statement } \\
\text { The employees in the food manufacturingindustry in Kerala are } \\
\text { not motivated to enhance their performance }\end{array}$ & $\begin{array}{l}\text { Statistical } \\
\text { applied }\end{array}$ & $\begin{array}{l}\text { tool } \\
\text { Onesults of testing of the } \\
\text { null hypothesis }\end{array}$ \\
\hline 01 & $\begin{array}{l}\text { The employees in the food manufacturing } \\
\text { industry in Kerala is not sufficientlyempowered in their roles. }\end{array}$ & $\begin{array}{l}\text { One samplet- } \\
\text { Aest }\end{array}$ & $\begin{array}{l}\text { Accepted } \\
\text { There is no significant relationship between empowerment and Correlation- } \\
\text { improvementin the performance of the employees in the foodcoefficient } \\
\text { manufacturing industry in Kerala }\end{array}$ \\
\hline 03 & Accepted \\
\hline
\end{tabular}

food manufacturing industry in Kerala. It is observed that the Testing null hypotheses also prove the same phenomenon. Most firms and managements are keen to empower their employees. The majority of employees accept the role of all these empowerment factors in improving their performance at work, though consistency in feedback has remained an issue. Therefore, it cannot be said that employees in the food manufacturing industry in Kerala are sufficiently empowered in their roles.

Testing and interpreting the hypothesis to find therelationship between different factors and their impact on employee performance reveals a not-so-significant relationship.Regarding the relationship betweenemployee empowerment and improved performance, it is found that the impact of work has remained the most preferred chosen factor, which according to the pattern of opinions, influences most the improvement in the performance of employees. The supervisor's involvement is the least important factor. Regarding the aspects of suggested ways to improve the performance of employees in the food manufacturingindustry in Kerala, the impact of work has been chosen as the most preferred option bythe most significant part of respondents. In contrast, the organizational culture has remained the most preferred option of the minor part of respondents.

\section{RECOMMENDATIONS}

Based on the above observations, thefollowing recommendations can be suggested. As the overall scenario is not favourablefor employee empowerment employees in the food manufacturing industry in Kerala,serious attention must be given to planned improvement. The impact of Covid 19 on an employee's personal and professional life is broad, so this study highly recommends empowerment activities to overcome this situation. As it is found that the employees' observation on the factors affecting individual performance is also inconsistent,strategic initiatives are recommended to collect their observations across hierarchy and improve their performance and the performance of the overall organizations regularly. As the study has shown that few factors are considered more important than others from employees' side for improving their performance, employers should have considered those preferred factors on a priority basis.

\section{CONCLUSION AND FUTURE SCOPE OF RESEARCH}

Employee empowerment and its impact on employee performance are widely researched areas in businessmanagement. In the contemporary corporate environment, the same has become more prominent due to the growingimportance of largescale corporate restructuring, the creation of autonomous work teams, and other significant developments. Food manufacturing industries have witnessed the large-scale transformation, and employeeempowerment has become a joint endeavour across the globe. Improvement in employee performance throughemployee empowerment has therefore become strategic essentiality and the abovestudy, though conducted at a microscopic scale, indicates the much to do things in the future. The research can be further enhanced and improved in the following manners: This research was carried out at a smaller scale, and a reasonably small sample was used for data collection. The impact-based limitation of this research was that it was only conducted on a selected number of food manufacturing industries in Kerala. Hence the findings of the study may be extended to the entire food manufacturing industry. The same can be extended in future research to obtain moreaccurate outcomes. A single source questionnaire has been usedin the present research as a primary form ofdata collection, and the data gathered fromthe respondents on these questionnairesmight have a slight chance of duplication ofanswers despite utmost caution attempted. A separate study can be conducted based ondifferences in respondents' opinions according to their designations, tenure ofemployment etc., on the issues of 


\section{International Advanced Research Journal in Science, Engineering and Technology \\ Impact Factor $7.105 \div$ Vol. 9, Issue 1, January 2022 \\ DOI: 10.17148/IARJSET.2022.9148}

employeeempowerment and employee performance,which has not been done in the presentstudy. This study focused on employee empowerment, and limited findings are there regarding the impact of Covid 19.

\section{REFERENCES}

1.Archna and Dr. M.P. Singh (2018) Et.Al., Journal of Management Research and Analysis (JMRA) "Employee Empowerment in Food and Beverage Industry."

2.Jaya Kumar. P \& Prof. Dr. A. Ananda Kumar (2017) Global Journal of Management and Business Research: An Administration and Management, "Employee Empowerment - An EmpiricalStudy."

3.Kyoung Ryoul Min, Reginald G. Ugaddan, and Sung Min Park (2016) "Is the Creative Tendency Affected by Organizational Leadership and EmployeeEmpowerment? An Empirical Analysis of U.S. Federal Employees."

4.Grace Chacha Busara (2016) "Impact ofEmployees Empowerment on OrganisationPerformance."

5.Indranil Bose (2018) School of Business, Academic Centre - the Ras Al Khaimah University of Bolton, the UnitedArab Emirates. "Employee Empowermentand Employee Performance: An EmpiricalStudy on Selected Banks in UAE."

6.Shilpa N.C., Dr. Amulya M. (2019) " Growth and Performance of Food Processing Industry in India."

7.Sambil Charles Mukwakungu, Charles Mbohwa and Sihle Manzana (2018) "The Impact of Employee Empowerment on Organisational Performance in A Flavoursand Fragrance Manufacturing Company inSouth Africa."

8.Dean Tjosvold and Haifa Sun (2005) "Effects of Power Concepts and Employee Performance on Managers' Empowering."

9.Tahira Michelle Probst (2005) Article inJournal of Occupational Health Psychology" Countering the Negative Effects of Job Insecurity Through Participative Decision Making: Lessons from The Demand-Control Model."

10.Harpreet Singh (2019) Selinus University of Sciences and Literature, School of Business and Media" The Impactof Employee Participation in Decision Making on Organisational Productivity."

11.Krishnaveni.R and Monica.R (2018) Int. J. Business Performance Management,Vol. 19, No. 4" Factors Influencing Employee Performance: The Role of Human Resource Management Practices and Work Engagement."

12.Sakib Imran Khan (2011) "HRDevolution: Rhetoric or Reality?"

Behdokht Rekabdar (2015) "Trust inThe Workplace: The Importance of An Employee's Perspective." .

13.Aniket. M. Kamble (2014)," Impact ofRewards and Recognition on Labour Productivity."

14.Kelly Tee Pei Leng (2013), "An Analysis of Written Feedback on ESLStudents' Writing."

15.Allison Rohner (1999) Rowan University" The Importance of Morale inThe Workplace."

16.Mustafa Demirkiran, Serap Taşkaya (2016) Relationship Between Employee Empowerment and Organizational Stress:A Research on Hospital Employee."

17.Riikka Lindholm (2013) "ManagingRetention by Engaging Employees in ACase Company."

18. Michelle Yit and Yuniros Bangun (2020) Jurnal Manajemen Teknologi" Employee Empowerment in The DecisionMaking Process: Evidence from The Foodand Beverage Industry in Indonesia."

19.Pitri Raj Adhikari (2020) "Impact of Teamwork on Organizational Productivity in Nepalese Commercial Banks." Management Dynamics Vol. 23, No. 2: 75-84, 2020.

20.Ipsita Mohapatra, Dr. Bijaya Kumar Sunday (2018) International Journal of Advanced Technology \& Engineering Research (IJATER)" Impact of EmployeeEmpowerment on Employee Performance."

21.Shilu Varghese, Dr.K. Aparna Rao (2018) Research Paper Impact Factor: 4. 695 Peer-Reviewed \& Indexed Journal" A Study on Empowerment Dimension and ItsImpact on Work Satisfaction of Lady Conductors of Kerala Transport Sector"

22.Minimal M. C. And Makesh K. G.2(2012) Full-Length Research Paper Empowering Rural Women in Kerala: AStudy on The Role of Self-Help Groups (SHGS).

23.Hassan, Saad Hassan, Sadia Shaukat and Muhammad Ali Asadullah (2014) Impact of Employee Training and Empowerment on Employee Creativity Through Employee Engagement: Empirical Evidence from The Manufacturing Sector of Pakistan."

24.Isabel Buila, Eva Martínezb, Jorge Matute (2018) "Transformational leadership and employee performance: Therole of identification, engagement, and proactive personality."

25.Mohand Tuffaha (2020) International Journal of Hospitality Management" Transformational Leadership and Employee Performance: The Role of Identification, Engagement, and ProactivePersonality."

26.Dr. Salini B Nair, Shitha. M. S (2018) "Journal of Economics and Management Sciences" The Determinants of Employee'sPerformance: A Literature Review.

27.Dr. Rajesh Rathore (2015)" International Journal for Innovative Research in Multidisciplinary Field" Roleof Employee Empowerment in Organizational Performance. 